\section{Fulfillment of the} Conditions of Law no. $302 / 2004$ on the European Arrest Warrant

\author{
Denisa BARBU1, \\ Nicolae Silviu PANĂ² \\ ${ }^{1}$ Lecturer PhD, Faculty of Law and \\ Administrative Sciences, Valahia \\ University of Targoviste, Romania, \\ denisa.barbu77@yahoo.com \\ ${ }^{2}$ Bachelor's degree from the University \\ of Bucharest, Faculty of Law, master's \\ degree from Nicolae Titulescu \\ University, specialization in Business \\ Law, lawyer in the Dambovita Bar, \\ silviunpana@gmail.com
}

Abstract: In the Romanian and European doctrine, taking into account the definition given by the European legislator in the normative act itself, the Framework "Decision no. 2002/584/JHA, the European arrest warrant was defined in a similar manner as the legislator did".

Thus, one jurisprudential decision states that: "from a legal point of view, the European arrest warrant is defined as a court decision issued by the competent judicial authority of an EU Member State, in order for another state to arrest and hand over a person who is wanted in order to stand for prosecution, trial or the execution of a custodial sentence or a security measure" (European Court of Justice, 2016).

Keywords: European arrest warrant, handing over of prisoners, requested person, pre-trial detention, conditions.

How to cite: Barbu, D., \& Pană, N. S. (2021). Fulfillment of the Conditions of Law no. 302/2004 on the European Arrest Warrant. Logos Universality Mentality Education Novelty: Law, 9(1), 33-41. https://doi.org/10.18662/lumenlaw/9.1/54 


\section{Introduction}

In a case pending before the "High Court of Cassation and Justice", it was requested to admit the appeal against the measure of pre-trial detention, according to art. 109 par. 4 related to art. 87 para. 1 letters c, d, e, with the application of art. 102 para. 5 letter b of Law no. 302/2004, to refuse the authorisation of handing over the requested person, "to reject the prosecutor's proposal and to decide the immediate release of the defendant, or to take one of the measures provided by art. 202 para. 4 letters b, c, d of the Criminal Procedure Code" for a period of 30 days of one of the measures provided by art. 202 para. 4 lit. b, c, d of the Criminal Procedure Code, because the criminal sentence of the Ploieşti Court of Appeal was considered by the appellant to be illegal and unfounded for the following reasons:

First of all, that the "European arrest warrant does not meet the basic conditions provided by art. 87 para. 1 letters c, d, e of the Law no. 302/2004", stating that: "(1) The European arrest warrant shall contain the following information: a) the identity and citizenship of the requested person; b) the name, address, telephone and fax numbers, as well as the e-mail address of the issuing judicial authority; c) the mention that there is a final court decision, of a warrant of pre-trial detention or of any other enforceable court decision having the same effect, which falls within the provisions of art. 89 and 97 of this law; d) the nature and legal classification of the crime, taking into account especially the provisions of art. 97; e) a description of the circumstances in which the crime was committed, including the time, place, degree of involvement of the requested person; f) the punishment that was ordered, if the judgment is definitive, or the punishment provided by the law of the issuing state for the committed crime; $g$ ) if possible, other consequences of the crime. (2) The European arrest warrant shall be drawn up in accordance with the form in Annex no. 1. (3) The European arrest warrant, once transmitted to the competent authority of another Member State, shall be translated into the official language or languages of the executing State or into one or more other official languages of the institutions of the European Union, which that State shall accept, in accordance with the declaration submitted to the General Secretariat of the Council of the European Union. (4) The European arrest warrant sent for execution to the Romanian authorities must be translated into Romanian or into one of the English and French languages".

Second, the appellant said that "the European arrest warrant is not based on the arrest warrant issued by the prosecutor" of the Orleans District Court, because 
only the number of the European arrest warrant was transcribed - namely warrant no. 20 140/103 - instruction no. 2- 21-40, dated November 23rd, 2021.

Third, the "decision on which the European arrest warrant is based" is issued on November 23rd, 2021- it was given no. 21.140 / 103 by the Criminal Prosecutor's Office - Instruction no. 2-21-40. In these circumstances, it ca be noted that the decision underlying the issuance of the European arrest warrant is subsequent to its issuance, because the European arrest warrant is issued under no. 20.140/103 - Instruction no. 2-21-40 at the Criminal Prosecutor's Office, and the decision underlying it received no. 21.140/103 - Instruction no. 2-21-40, both dated November 23rd, 2021, and issued by the same judicial body, respectively the Prosecutor's Office attached to the Orleans Court.

Considering that the Deputy Prosecutor, issued the European arrest warrant before any national arrest warrant was issued in order to justify issuing the European arrest warrant, this national arrest warrant being subsequently issued by another prosecutor, under no. 20.140/103 - Instruction no. 2-21-40, in terms of basic validity conditions, we can conclude that the European arrest warrant arrest does not meet the validity conditions required by “art. 87 para. 1 letter c of Law no. 302/2004".

\section{European arrest warrant - concept and definition}

In view of the provisions of the European legislation, "as well as the opinions expressed in the doctrine", we consider that: "the European arrest warrant is a judicial decision, adopted by the competent judicial authority of a Member State, based on an internal decision (an arrest warrant or a warrant for the execution of a sentence, of an educational measures or a security measure carried out with the deprivation of liberty), in order for another state to arrest and hand over a person who is wanted in order to stand for prosecution, trial or the execution of a custodial sentence, an educational measure or a security measure carried out with the deprivation of liberty" (European Court of Justice, 2021).

The definition of the European arrest warrant also included the obligation to have an internal arrest warrant, previously issued by the competent judicial authorities of the requesting Member State, justifiably considering that the nonexistence/subsequent issuance of this document implicitly leads to the impossibility of issuing an European arrest warrant and, respectively, to its execution.

"It is considered that the provisions of art. 1 para. 1 of the Framework Decision no 2002/584/JHA (Council of the European Union, 2002), which defines the European arrest warrant", must be supplemented by the inclusion of the trial 
phase, given that sometimes the presence of the defendant before the court at this stage of the criminal proceedings is required (Boroi, 2021).

According to the provisions of the European Framework Decision, the European arrest warrant will be drawn up in writing, according to the form established and provided in the annex of the Framework Decision and will contain the following information "(art. 87 of the Law no. 302/2004 on international cooperation in criminal matters)": "the identity and citizenship of the wanted person; the name, address, telephone and fax numbers and e-mail address of the issuing judicial authority; the mention that there is a final court decision, of a warrant of pre-trial detention or of any other enforceable court decision having the same effect, which falls within the provisions of art. 1 and 2; the nature and legal classification of the crime, especially in compliance with art. 2; the description of the circumstances of the crime, including the time, place and degree of involvement of the person wanted for the crime; the imposed sentence, in the case of a final judgment, or the series of penalties provided for by the law of the issuing Member State; as far as possible, other consequences of the crime" ("Article 8 of the Framework Decision 2002/584/JHA").

It follows from the above provisions that, in order to issue an European arrest warrant, a number of absolutely necessary conditions must be met, depending on the stage of the criminal proceedings in the Member State that issued the warrant.

This examination is all the more necessary as the conditions imposed by the European normative act differ from one phase to another of the criminal proceedings.

\section{Conditions for issuing an European arrest warrant}

In order for an European arrest warrant to be issued in the criminal investigation phase, a number of conditions must be met, including the requirement that an arrest warrant was issued against that person by the competent judicial authorities of the sentencing Member State.

We point out that, although this condition is not explicitly mentioned in the text of the European normative act, we consider that it is necessary to fulfill it. Moreover, the European arrest warrant is a judicial decision which is taken only in addition to and after the issuance of the arrest order by the xcompetent judicial bodies of the requesting Member State. In this context, at the time of the issuance of the pretrial detention warrant, there can be no link between it and the European arrest warrant. 
The European arrest warrant shall always be issued by the competent judicial authorities of the concerned Member State, and only if the necessary conditions required by national law are met in order for such a custodial measure to be ordered. In other words, if the European arrest warrant is issued both under the European law and the national law transposing that European law into the national law, the national arrest warrant shall be issued only in accordance with the national law of the sentencing Member State.

In our opinion, the subsequent issuance of a pre-trial detention warrant will make it impossible to issue an European arrest warrant, even if the wanted person is hiding on the "territory of another EU Member State". From the examination of the content of the European arrest warrant, as provided in the special law, it is found that there is a perfect identity between its provisions and the provisions of art. 8 para. 1 of the European framework normative act.

Regarding the executory character of the court decision, "in the judicial practice it was decided that" (Ciobanu, 2013) after the prosecutor notifies the court, in case "the European arrest warrant does not contain the information currently provided in art. 87 para. 1 letter c of Law no. 302/2004 and in art. 8 para. 1 letter c of the Framework Decision no. 2002/584 / JHA", regarding the enforceability of the court decision indicated in the European arrest warrant, the court requests this information from the issuing judicial authority, based on the provisions of "art. 90 para. 12 of Law no. 302/2004", according to which, if the court considers that the request for additional information or guarantees is required in the case of the issuing judicial authority, the court postpones the case, establishing "a deadline for receiving the requested data", which may not exceed 10 days.

In the recent doctrine (European Commission, 2017) it was argued that, on the other hand, as it results from annex no. 1 of Law no. 302/2004, the European arrest warrant is specified in a request for arrest and surrender, or, precisely the decision the national pre-trial detention warrant, which is the basis of the European arrest warrant, is recognized without any other formality, based on the principle of mutual recognition and trust.

In this context, starting from the very definition of the European arrest warrant in the European Framework decision examined in the previous section of this article, it follows that, in all cases, the "European arrest warrant is issued for the purpose" of enforcing a national judicial decision. In case an European arrest warrant is issued by a judicial authority of a Member State, without being based on a 
previous internal judicial decision, the requested competent Romanian judicial authorities will not execute it.

In this sense, the specialized legal literature (Boroi, 2021) states that the issuance of the "European arrest warrant on the basis of a European arrest warrant" which does not include a previous internal arrest warrant, but is limited to the need to ensure the presence of the requested person at trial (ie the equivalent of an arrest warrant issued by an issuing Member State (in particular Spain), and on the basis of which a European arrest warrant is not limited to the provisions of Article 87 (1) (c)) and does not with an internal arrest warrant, so that it cannot be executed by the Romanian judicial authorities, imposing the rejection of the request for the execution of such a European arrest warrant, the judicial practice being oriented in this sense.

As such, a report was prepared by the EU Council (No 15317/1/2007) for Hungary, which recommended to this Member State to reconcile its national legislation with that of the European Framework Decision, in the sense that the issuance of a European arrest must always be preceded by a national arrest warrant, because a European arrest warrant issued by the Hungarian judicial authorities cannot be considered a national arrest warrant at the same time.

Nor can it be disregarded that the fourth round of mutual evaluation reports on the "The practical application of the European Arrest Warrant and corresponding surrender procedures between Member States", carried out by the EU Council (2009), and the Council's draft conclusions - "Follow-up to the recommendations of the final report on the fourth round of mutual evaluations on the European arrest warrant" during the Spanish Presidency of the EU Council (2011) includes, in para. 2, the recommendation to use alternative measures, namely: “a) the use of Council Framework Decision 2008/909/JHA of November 27th 2008 on the application of the principle of mutual recognition of judgments in criminal matters which impose sentences or measures of deprivation of liberty for the purpose of their execution in the European Union; b) the use of less coercive instruments in the field of legal aid: the hearing of the requested person by videoconference; citing the requested person; hearing the requested person through a rogatory commission; c) the use of the Schengen Information System in order to establish the place of residence or domicile of the requested person".

"The execution of the European arrest warrant is subject to the principle of mutual recognition and trust", a principle expressly mentioned in the provisions of para. 6 and 10 of the preamble of the Framework Decision no. 2002/584/JHA and 
in the provisions of art. 84 para. 2 of Law no. 302/2004 on international judicial cooperation in criminal matters (the Romanian special law).

Another condition that must be met "for the issuance of a European arrest warrant" is that the requested person evade the execution of a pre-trial detention warrant. Withdrawal from the pre-trial detention warrant means a specific attitude and conduct of the person against whom such a warrant has been issued, whereby they hide in the territory of any other Member State and thereby prove that they do not intend to comply with the pre-trial detention order (Boroi, 2021).

Therefore, in our opinion, in order to prove the evasion of the pre-trial detention order, a simple search of the person in question at their home or residence is not enough, but other activities must be carried out.

Among the activities that, this time, are a matter for police activity, we mention the following: investigations and verifications in the locality of domicile and/or residence of the requested person, investigations and verifications at their workplace, investigations and verifications in their entourage, verifications in the records of the national police and of the National Administration of Penitentiaries, the summoning of the person in question at their domicile and/or residence etc.

Only after the exhaustion of these and other activities, imposed by the particularities of each case, and if the person is not identified and implicitly the warrant of pre-trial detention cannot be executed, it can be concluded that the person in question is evading the execution of the warrant of pre-trial detention, in which case the European arrest warrant shall be issued.

In this sense, in judicial practice it was decided that: if the European arrest warrant did not indicate the national arrest warrant that was the basis for issuing the European one, or the national warrant was issued later, the requirement provided in art. 87 para.1 letter c of Law no. 302/2004 was not respected, therefore the request for the execution of the European arrest warrant was rejected.

In the case mentioned in the introduction of this article, it was claimed that the European arrest warrant was issued on November 23rd, 2021, and within 24 hours, respectively on November 24th, 2021, the execution of the European arrest warrant was admitted by the court. Furthermore, in relation to "the person arrested on the basis of an European arrest warrant, the executing judicial authority has the power to decide whether the requested person should remain in detention, in accordance with their own national law".

Provisional release is possible "at any time, in accordance with the national law of the executing Member State, provided that the competent authority of that 
Member State takes whatever measures it deems necessary to prevent the escape of the requested person" (art 12 of Framework Decision 2002/584/JHA). Regarding the description of the facts and circumstances as provided in art. 87 para. 1 letter $\mathrm{d}$ and the following of Law no. 302/2004, in the case we mentioned in the introduction of this article, it was noted that in table 6 letter e, according to the European arrest warrant, the criminal activity is summarized as follows: "the investigations ... allowed the prosecution of 10 people from Romania, including the requested person, in connection with approximately 20 thefts committed on French territory during February-November 2021".

The description of the facts must correspond to the incriminated actions, by indicating the elements strictly necessary to frame the deed in the typicality of the crime. The facts must be presented by mentioning the relevant events from the point of view of the existence of a crime, making a clear delimitation of the facts that fall within the content of crimes and are submitted to the judicial bodies for a criminal investigation (premise, qualification of the active subject, material element, legal element, related circumstances that may be relevant for the individualization of the punishment or the settlement of civil claims) (Udroiu, 2019).

Given that in the case provided as an example, the crime consisted of approximately 20 thefts, commited in a continuous manner, it would have been necessary to indicate each material act, individualized by the time and circumstances of the commission and the contribution of each defendant to the crime. In this case, it was necessary to specify the number of material acts that fall within the "content of the objective side of the crime", to indicate the concrete manner retained in the charge of the defendant and so on.

\section{Conclusions}

From the description of the deed in the European arrest warrant, the context and manner in which the alleged material acts were committed are not clear and, as such, it cannot be said that the object of the judgment is outlined, as has been the case in judicial practice in a number of cases, after interpreting the provisions of art. 328 para. 1 of the Criminal Procedure Code.

Therefore, the generic presentation of the overall image of the criminal activity, without specifying in a concrete and detailed manner, with pertinent reference to the evidence supporting the claims, the constituent facts of the criminal activity of the defendant, with a detailed description of the circumstances, as provided in art. 1 letter d of Law no. 302/2004, does not correspond to the legal provisions. 


\section{References}

Boroi, A. (2021). Cooperarea internationala in materie penala [International judicial cooperation in criminal matters] (2nd ed.). Universul Juridic.

Ciobanu, A. (2013). Criminal defense in the context of European criminal justice [PowerPoint Presentation]. http://www.eracomm.eu/defence counsel/kiosk/pdf/1_Ciobanu_presentation.pdf

Council of the European Union. (2002, July 18). 2002/584/JHA: Council Framework Decision of 13 June 2002 on the European arrest warrant and the surrender procedures between Member States. Official Journal of the European Union, 190. https://eur-lex.europa.eu/resource.html?uri=cellar:3b151647-772d-48b0-ad8c0e4c78804c2e.0004.02/DOC 1\&format $=$ PDF

Council of the European Union. (2007). Decision no. 15317/1/2007. Evaluation report on the fourth round of mutual evaluations "The practical application of the european arrest warrant and corresponding surrender procedures between member states". Report on Hungary. https://data.consilium.europa.eu/doc/document/ST-15317-2007-DCL-1/en/pdf

Council of the European Union. (2009). Final report on the fourth round of mutual evaluations The practical application of the European Arrest W arrant and corresponding surrender procedures between Member States. https://www.eumonitor.eu/9353000/1/j9vvik7m1c3gyxp/vj6ipihqlpv1

Council of the European Union. (2011). Follow-up to the recommendations of the final report on the fourth round of mutual evaluations on the European arrest warrant during the Spanish Presidency of the EU Council. https://data.consilium.europa.eu/doc/document/ST5860-2011-INIT/en/pdf

European Commission. (2017). Manual pentru emiterea şi executarea unui mandat european de arestare [Handbook for issuing and executing a European arrest warrant]. https://eur-lex.europa.eu/legalcontent/RO/TXT/PDF/?uri=CELEX:52017XC1006(02)\&from=ES

European Court of Justice. (2016). Case C-452/16 PPU. https://eur-lex.europa.eu/legalcontent/RO/ALL/?uri=CELEX:62016CJ0452

European Court of Justice. (2021). Svishtov Regional Prosecutor's Office vs. PI (case C-648/20 PPU). https://curia.europa.eu/juris/document/document print.jsf;jsessionid=D017C10 DFE1175CACD9EF641C7E44ED0?docid $=237648 \&$ text $=\&$ dir $=\&$ doclang $=\mathrm{RO} \&$ part $=1 \&$ occ $=$ first \&mode $=$ DOC\&pageIndex $=0 \&$ cid $=4640938$

Romanian Parliament. (2010, July, 15). Lege nr. 135/2010 privind Codul de procedura penala [Law no. 135/2010 regarding the Criminal Procedure Code]. Monitorul Oficial al Romaniei, 486. http://legislatie.just.ro/Public/DetaliiDocumentAfis/120609

Romanian Parliament. (2004). Lege nr. 302/2004 privind cooperarea judiciara internațională în materie penală [Law no. 302/2004 on international judicial cooperation in criminal matters]. Monitorul Oficial al Romaniei, 411, 2019, May 27. http://legislatie.just.ro/Public/DetaliiDocument/53158

Udroiu, M. (2019). Procedura penala. Partea specială [Criminal procedure. Special part]. C.H. Beck. 